\title{
FAKTOR-FAKTOR YANG BERHUBUNGAN DENGAN KENAIKAN BERAT BADAN IBU HAMIL KURANG ENERGI KRONIS
}

\author{
Rani Widiyanti ${ }^{1}$, Nina Nirmaya Mariana ${ }^{2}$ \\ ${ }^{1,2)}$ Poltekkes Kemenkes Tasikmalaya \\ widirani85@gmail.com
}

\begin{abstract}
ABSTRAK
Kurang Energi Kronis (KEK) merupakan keadaan ibu menderita kekurangan makanan yang berlangsung menahun (kronis) sehingga menimbulkan gangguan kesehatan. Ibu hamil cenderung mengalami penambahan berat badan dikarenakan kebutuhan nutrisi bertambah untuk perkembangan janin. Tujuan penelitian ini untuk mengetahui faktorfaktor yang berhubungan dengan kenaikan berat badan. Manfaatnya sebagai dasar pengambilan kebijakan mencegah terjadinya KEK pada kehamilan. Penelitian Mixed Method Embedded Konkuren dengan pengambilan sampel secara purposive sampling dan snow ball. Pengumpulan data melihat buku KIA dan wawancara yang dilakukan Juli s.d September 2018 pada 33 ibu hamil di Puskesmas Jagasatru, Kesambi, Pekalangan dan Nelayan. Data dianalisis menggunakan t-test, chi-square serta koding. Hasil penelitian menunjukkan tidak ada hubungan antara usia, paritas, pendidikan dan pekerjaan dengan kenaikan berat badan. Rata-rata kenaikan badan ibu dengan KEK hingga umur kehamilan 24 minggu adalah $4 \mathrm{~kg}$. Hasil analisis didapatkan $p$-value $<0,05(0.000)$ artinya terdapat perbedaan kenaikan berat badan yang bermakna pada ibu hamil KEK usia kehamilan 8 minggu dengan kehamilan 24 minggu. Kenaikan tersebut terjadi berkat kontribusi keluarga dengan penyediaan makanan yang bergizi minimal $3 \mathrm{x}$ sehari, melibatkan dalam mengurus rumah, pola tidur yang cukup, dan menemani dalam pemeriksaan ANC minimal 8 kali sebelum umur kehamilan 24 minggu.
\end{abstract}

Kata kunci : ibu hamil, kenaikan berat badan, kurang energi kronis

\section{Abstract}

Chronic Lack of Energy is a condition where the mother suffers from a chronic shortage of food that causes health problems. Pregnant women tend to gain weight because of the increased nutritional needs for fetal development. The purpose of this study was to determine the factors associated with weight gain. The benefit is as a basis for making policies to prevent Chronic Lack of Energy in pregnancy. Mixed-Method Embedded Concurrent Research with purposive sampling and snowball sampling. Data collection looked at the KIA book and interviews conducted from July to September 2018 on 33 pregnant women at Jagasatru, Kesambi, Pekalangan and Nelayan Health Centers. Data were analyzed using T-test, Chi-square and coding. The results showed no relationship between age, parity, education and work with an increase in body weight. The average increase in the mother's body with Chronic Lack of Energy to 24 weeks of gestation is $4 \mathrm{~kg}$. The analysis results showed that a p-value $<0.05$ (0.000) means a significant difference in weight gain in pregnant women at eight weeks of gestation and 24 weeks of gestation. This increase was due to the family's contribution by providing nutritious food at least three times a day, involving taking care of the house, having good sleep patterns, and accompanying ANC examinations at least eight times before 24 weeks of gestation.

Keywords: pregnant woman, weight gain, chronic energy deficiency 


\section{PENDAHULUAN}

Prevalensi KEK pada kehamilan secara global 35-75\% bermakna tinggi pada trimester tiga dibandingkan trimester satu dan dua, sedangkan Indonesia merupakan urutan ke empat terbesar setelah India dengan prevalensi $35,5 \%$. WHO juga mencatat $40 \%$ kematian ibu di negara berkembang berkaitan dengan kekurangan energi kronis. (WHO, 2015)

Ibu hamil dengan KEK berisiko melahirkan bayi dengan Berat Badan Lahir Rendah (BBLR) (Mahirawati, 2014). Bayi dengan BBLR hingga saat ini masih menjadi masalah di seluruh dunia karena merupakan penyebab kesakitan dan kematian pada bayi baru lahir (Lubis, 2013). Faktor-faktor nutrisi pada ibu yang terbukti berhubungan dengan berat lahir adalah berat badan sebelum hamil dan penambahan berat badan selama kahamilan (Varney, 2006) Penambahan berat badan selama hamil menjadi salah satu indikator gizi ibu hamil. Kualitas anak yang dilahirkan bergantung pada pemenuhan gizi ibu hamil. Selain itu juga dapat menurunkan Angka kematian Ibu dan Anak (AKI dan AKB). Pembangunan di bidang kesehatan tidak bisa dilepaskan dari upaya mewujudkan kesehatan anak sedini mungkin sejak dalam kandungan. (Manik \& Rindu, 2017)

Angka Kecukupan Gizi (AKG) Amerika Serikat yang ditetapkan oleh Food and Nutrition Board of The National Academy of SciencesNational Research Council mengindikasikan bahwa secara keseluruhan seorang wanita hamil harus menambahkan 300 kalori selain asupan 2200 kalori yang dianjurkan dan 60 gr protein, yakni 10 gram per hari (Varney, 2006). Status gizi ibu sebelum hamil juga akan memengaruhi perbedaan kebutuhan kenaikan berat badan ibu selama kehamilan. Penilaian status tersebut didasarkan pada indeks massa tubuh (IBM atau berat badan untuk tinggi badan).

Persentase Ibu Hamil KEK di Indonesia mengalami kenaikan 2,9\% dari tahun 2015 yaitu $13,3 \%$ menjadi $16,2 \%$ pada tahun 2016. Pada tahun yang sama persentase ibu hamil berisiko KEK yang mendapatkan makanan tambahan adalah 79,3\% sedangkan angka lebih tinggi di Jawa Barat yaitu 80\% (Kementerian Kesehatan Republik Indonesia, 2017)

Pemerintah telah mengupayakan perbaikan gizi pada ibu Hamil dengan KEK melalui pendampingan, pemberian makanan tambahan (PMT) Pemulihan, konseling dan penyuluhan pada tahun 2016. Pemberian Makanan Tambahan Pemulihan Ibu hamil KEK bersumber dana dari Bantuan Operasional Puskesmas (BOK) dan JKN, serta biskuit bumil KEK dari Kemenkes. Pemberian Makanan Tambahan tersebut ternyata belum dapat memberikan pengaruh terhadap penurunan kasus Ibu hamil KEK di Kota Cirebon (Badan Pusat Statistik Kota Cirebon, 2016). Namun, hasil ini tidak sejalan dengan penelitian sebelumnya yang dilakukan di Lombok bahwa terjadi peningkatan berat badan ibu hamil KEK setelah diberikan makanan tambahan berupa biskuit berbahan lokal.(Chandradewi, 2015)

Kenaikan berat badan pada ibu hamil dipengaruhi oleh beberapa faktor diantaranya keseimbangan energi, status gizi ibu prahamil, kadar HB, sosiodemografi (sosio-ekonomi, usia, paritas dan ras), lingkungan (geografi dan iklim), perilaku ibu ( kebiasaan merokok, konsumsi alkohol dan stres) dan prenatal care.(Fikawati S, Safiq A, dan Karima K, 2015)

Ketika hamil di usia muda biasanya memiliki kebiasaan konsumsi yang buruk seperti makan sedikit dan tidak teratur selain itu terjadi kompetisi antara ibu dan janin karena menuntaskan masa pertumbuhan. Padahal pada ibu hamil usia tua fungsi organ melemah sehingga memerlukan tambahan energi yang akan memengaruhi peningkatan berat badan. Kehamilan anak pertama dengan anak selanjutkan 
akan berbeda dalam pengetahuan pemenuhan gizi selama kehamilan. Hal serupa juga terkait dengan jenjang pendidikan dan pekerjaan ibu semakin tinggi jenjang pendidikan maka pengetahuan ibu lebih baik terkait pemenuhan gizi pada kehamilannya. Begitu pula dengan kondisi ibu yang bekerja maka bertambah penghasilan dalam upaya pemenuhan kebutuhan selama hamil.

Survei yang dilakukan pada penelitian sebelumnya didapatkan hasil bahwa faktor yang paling tinggi berpengaruh pada kenaikan berat badan ibu hamil KEK trimester tiga adalah peran bidan dibandingkan dengan pola makan, konseling, sumber informasi dan motivasi di Puskesmas Kecamatan Kayumanis Kota Bogor tahun 2017.(Manik \& Rindu, 2017)

Penelitian ini bertujuan untuk mengetahui faktor intrinsik dan ekstrinsik yaitu umur, paritas, pendidikan, pekerjaan dan keterlibatan keluarga berhubungan dengan kenaikan berat badan ibu hamil dengan KEK selama kehamilan di Kota Cirebon melalui data buku KIA dan metode wawancara sehingga penelitian diharapkan dapat menjadi masukan dan pertimbangan dalam upaya meningkatkan pelayanan kebidanan khususnya dalam pemberian asuhan pada ibu hamil KEK sesuai dengan kebutuhan

\section{METODOLOGI}

Penelitian ini merupakan penelitian Mixed Method Embedded Konkuren. Pada penelitian ini pengumpulan data penelitian kuantitatif dan kualitatif dalam waktu bersamaan. Penelitian kualitatif bersarang pada penelitian kuantitatif yaitu menjelaskan proses terjadinya hubungan antara variabel bebas dengan variabel independen. Pengumpulan data dilakukan bulan Juli -September 2018. Populasi ibu hamil KEK berjumlah 55 orang. Diperoleh sampel $33 \mathrm{ibu}$ hamil trimester 2 yang didiagnosis KEK pada umur kehamilan trimester 1, tanpa penyakit lainnya dan terdapat data pemeriksaan Berat Badan. Jumlah sampel penelitian kualitatif yaitu 10 orang ibu hamil, 1 orang keluarga dan 1 orang bidan. Pengambilan sampel penelitian kuantitatif dengan pusposive sampling. Adapun untuk pengambilan sampel penelitian kualitatif menggunakan snow ball. Intrumen yang digunakan kuesioner dan pedoman wawancara. Seluruh data yang diperoleh ditabulasi dan diperoleh koding. Data hasil penelitian akan menggunakan t-test dan chi-square.

\section{HASIL}

Penelitian ini dilaksanakan selama 3 bulan mulai 1 Juli hingga 30 September 2018 di Kota Cirebon yaitu Puskesmas Jagasatru, Kesambi, Kalijaga dan Pekalangan mengenai umur, paritas, pendidikan, pekerjaan dan keterlibatan keluarga yang berhubungan dengan kenaikan berat badan pada ibu hamil KEK. Adapun perbandingan berat badan ibu hamil umur 8 minggu dengan 24 minggu terdapat pada tabel 1 .

Tabel 1. Perbandingan Berat Badan Ibu Hamil dengan KEK pada Umur Kehamilan 8 Minggu dengan Umur Kehamilan 24 minggu

\begin{tabular}{ccccccc}
\hline Berat Badan & Mean & Rentang & SD & Shapiro-wilk & $\boldsymbol{t}$ & Nilai $\boldsymbol{p}$ \\
\hline Berat Badan UK 8 minggu & 42,561 & $33,5-56,0$ & 5,62 & 0,470 & $-6,103$ & \multirow{2}{*}{000} \\
Berat Badan UK 24 minggu & 46,591 & $35,0-55,0$ & 5,17 & 0,465 & & \\
\hline Uji
\end{tabular}

Uji Dependent T test

Kenaikan Badan pada usia kehamilan 8 minggu dan 24 minggu. Setelah tabulasi dilakukan uji normalitas dan keduanya memiliki data normal $(\mathrm{p}>0,05)$. Rerata Berat Badan umur kehamilan 8 minggu adalah 42,561 $\mathrm{kg}$ dan rerata berat badan pada umur kehamilan 24 minggu 
adalah 46,591 kg. Hasil uji dependent t-test menunjukkan pada ibu hamil KEK terdapat perbedaan kenaikan berat badan yang bermakna pada usia kehamilan 8 minggu dengan kehamilan 24 minggu yaitu $\mathrm{p}=0.000$.

Tabel 2. Hubungan Umur, Pendidikan, Paritas dan Pekerjaan dengan Kenaikan Berat Badan Ibu Hamil dengan KEK

\begin{tabular}{|c|c|c|c|c|c|}
\hline \multirow{2}{*}{ Karakteristik } & \multicolumn{2}{|c|}{ Tidak naik } & \multicolumn{2}{|c|}{ Naik } & \multirow{2}{*}{ Nilai $p$} \\
\hline & $\mathbf{n}$ & $\%$ & $\mathbf{n}$ & $\%$ & \\
\hline \multicolumn{6}{|l|}{ Umur (tahun) } \\
\hline Berisiko $(<20$ dan $>35)$ & 0 & 0 & 3 & 100 & \multirow{2}{*}{1,00} \\
\hline Tidak Berisiko (20-35) & 5 & 16,7 & 25 & 83,3 & \\
\hline \multicolumn{6}{|l|}{ Pendidikan } \\
\hline Pendidikan rendah (SD-SMP) & 1 & 7,7 & 12 & 92,3 & \multirow{2}{*}{0,625} \\
\hline Pendidikan Tinggi (SMA-PT) & 4 & 20,0 & 16 & 80,0 & \\
\hline \multicolumn{6}{|l|}{ Pekerjaan } \\
\hline Tidak Bekerja & 3 & 11,5 & 23 & 88,5 & \multirow{2}{*}{0,282} \\
\hline Bekerja & 2 & 28,6 & 5 & 71,4 & \\
\hline \multicolumn{6}{|l|}{ Paritas } \\
\hline Primipara & 4 & 20,0 & 16 & 80,0 & \multirow{2}{*}{0,625} \\
\hline Multipara & 1 & 7,7 & 12 & 92,3 & \\
\hline
\end{tabular}

Uji Chi-quare

Mayoritas ibu hamil dengan KEK terjadi kenaikan berat badan baik yang usia berisiko (100\%) maupun tidak berisiko (83,3\%) dengan p-value 1,00 yang berarti tidak ada hubungan antara usia dengan kenaikan berat badan ibu hamil KEK.

Sama halnya dengan pendidikan terjadi kenaikan berat badan baik pada ibu dengan pendidikan rendah $(92,3 \%)$ maupun yang berpendidikan tinggi (80\%) dengan p-value 0,625 yang berarti tidak ada hubungan antara tingkat pendidikan dengan kenaikan berat badan ibu hamil KEK.

Begitu pula dengan pekerjaan terjadi kenaikan berat badan baik pada ibu yang tidak bekerja $(88,5 \%)$ maupun ibu yang bekerja (71,4\%) dengan $p$-value 0,282 yang berarti tidak ada hubungan antara pekerjaan dengan kenaikan berat badan ibu hamil KEK.

Hal tersebut berlaku juga pada paritas bahwa terjadi kenaikan berat badan baik ibu primiparitas (80\%) maupun ibu multiparitas $(92,3 \%)$ dengan $p$-value 0,625 yang berarti tidak ada hubungan antara paritas dengan kenaikan berat badan ibu hamil KEK.

Hasil wawancara mendalam kepada ibu hamil dengan KEK secara snow ball hingga diperoleh data jenuh dari 33 orang didapatkan 10 responden kemudian dilakukan trianggulasi dengan hasil wawancara bidan dan orang tua responden.

Mereka serumah dengan orangtua atau mertua sesuai dengan pernyataan responden bahwa "saya tinggal dengan orangtua"

Sebelum hamil asupan makanan kurang,

"sebelum hamil susah makan, malas sekarang mah alhamdulillah"

Kenaikan berat badan terjadi di trimester 2.

"Satu bulannya harus naik $1 \mathrm{~kg}$ atau 2 kg. waktu hamil diawal nga naik nga turun segitu aja, pas naik tuh pas 4 bulan baru naik" 
Aktivitas harian rutin,

"bangun tidur jam 5 jalan-jalan habis itu makan minum obat, mandi habis itu istirahat kadang duduk, klo tidur jam 12 an makan siang, udah midang ke depan. Midang duduk aja sambil ngobrol sampai jam 16 baru beberes rumah nyapu, ngepel aja soalnya mau masak dan cuci piring ngga boleh sama ibu”

Masakan dibuat sendiri oleh orangtua/ mertua, makan teratur 3 kali dalam sehari,

'Yang ada aja. Contohnya mba, pas kebetulan mamah masak eh jual nasi lengko, agak sore ya beli yang ada aja, kadang masak telur.

"3 kali sehari lauknya nasi kadang telur sekarang lagi hamil yang penting buat janin, ikan telur ayam yang penting banyak vitaminnya. Contoh hari ini masak udang sama sayur bening dan nasi 1 piring, sayur 1 mangkok, udang secukupnya"

Ada pantangan makanan tapi ibu tetap memakannya.

"kata orang hamil tidak makan blakutak dan udang apa malah bagus makanan begitu, tetap dimakan, neng aja mangan blakutak nggko anake ireng, maju mundur. tapi tetap makan lilahitaala, itu makanan bagus. 2 minggu sekali makan ikan diacar, blakutak, kerang"

Tidak ada gangguan pola tidur,

"malam sengantuknya kadang jam 9 wis ngantuk ini pada maen. Ngga tidur sih blek-blek bae kebo pinginnya tidur bae

Diakhir pemeriksaan rutin di bidan dan keluarga berupaya menjaga kehamilan ibu.

"Suami sih sering nurut coba klo disuruh bidan atau dokter, dipikirin jadi mau. Langsung minta priksa, terus diikutin berkurang yang dirasakan. Kasihan dedenya jadi ngikutin saran."

Periksa kadang ke dokter, bidan, sarannya sama makan yang banyak, makan bergizi, istirahat yang cukup.

\section{PEMBAHASAN}

\section{a. Kenaikan Berat Badan Ibu Hamil KEK}

Penambahan berat badan ibu hamil dengan KEK terjadi pada trimester 2 yaitu 24 minggu sesuai dengan hasil penelitian yaitu $p$-value $=0.000$. Hal ini sejalan dengan pedoman penanggulangan KEK yang dikeluarkan Kementerian Kesehatan bahwa kenaikan berat badan pada ibu hamil KEK pada trimester I minimalnya $1 \mathrm{~kg} / \mathrm{bulan}$ dan kenaikan pada trimester 2 dan 3 adalah 0,45-0,59 kg/minggu. (Kementerian Kesehatan Republik Indonesia, 2015)

Berdasarkan data kualitatif pada trimester 1 ( 8 minggu) terjadi berat badan yang tetap atau menurun, setelah memasuki awal trimester II atau 16 minggu keluhan berkurang dan ibu dapat mengonsumsi makanan sesuai anjuran dan peningkatan berat badan dapat terlihat pada minggu ke- 24.

Status gizi pada awal kehamilan ditentukan dengan pemeriksaan berat badan. Penimbangan dilakukan sedikitnya 4 kali yaitu 1 kali pada trimester I, 1 kali pada trimester II dan 2 kali pada trimester III. Pertambahan trimester I merefleksikan perubahan cadangan ibu dan perubahan fisiologis tubuh serta pembentukan organ tubuh janin dan plasenta. Selanjutnya pada trimester II hanya hasil dari pertumbuhan dan perkembangan janin sedangkan pada trimester III pertambahan berat badan akibat perubahan tubuh ibu juga pertumbuhan janin dan plasenta serta menigkatnya volume cairan.

Asupan makanan lebih kecil dari kebutuhan tubuh maka tidak terjadi kenaikan berat badan. Hal tersebut menandakan ketidakseimbangan antara asupan makanan dengan kebutuhan tubuh sehingga selama hamil ibu harus mengalami kenaikan Berat Badan yang sesuai agar tidak terjadi BBLR pada bayi yang akan mengganggu pertumbuhan dan perkembangan selanjutnya. 


\section{b. Hubungan Umur, pendidikan, pekerjaan dan paritas dengan kenaikan berat badan}

Berdasarkan tabel 2 bahwa tidak ada hubungan antara umur, pendidikan, pekerjaan dan paritas dengan kenaikan berat badan ibu hamil KEK. Hal ini sejalan dengan penelitian yang dilakukan di Karanganyar bahwa tidak ada hubungan antara usia ibu dengan kenaikan berat badan ibu hamil trimester III. (Sri \& Putri, 2018)

Pada penelitian ini baik ibu yang usia berisiko maupun yang tidak berisiko mayoritas mengalami kenaikan. Hal ini dapat dikarenakan responden mayoritas berada di usia tidak tidak berisiko yaitu 20-35 tahun. Hal tersebut sejalan dengan penelitian yang dilakukan Mahirawati bahwa ibu hamil KEK rentang usia 21-34 tahun, menikah diumur 17 tahun dan pertama kali hamil pada usia 18-20 tahun.(Mahirawati, 2014)

Kebutuhan gizi seseorang akan berbeda pada tiap tahapan umur. Semakin muda seorang wanita itu hamil maka akan menbutuhkan gizi yang semakin banyak karena dibutuhkan untuk perkembangan dan pertumbuhan janin serta tubuhnya. Fungsi organ yang semakin melemah juga mempengaruhi kebutuhan gizi seseorang. Pada ibu hamil dengan umur lebih tua membutuhkan energy lebih besar untuk mencukupi aktivitas yang lebih dengan fungsi organ tubuh yang melemah sehingga diperlukan tambahan energi yang cukup dalam mendukung kehamilannya. (Huliana, 2010).

Penelitian yang dilakukan di Semarang Bahwa tidak ada hubungan antara paritas dan pendidikan dengan status gizi ibu hamil. (Bunga Widita Kartikasari, Mifbakhuddin, 2011)Pada penelitian ini baik ibu yang primipara maupun multipara mayoritas mengalami kenaikan Berat Badan dan mayoritas ibu hamil dengan KEK dengan kehamilan anak pertama. Pada ibu hamil dengan kehamilan pertama atau kehamilan lebih dari empat mayoritas mengalami Kekurangan Energi Kronik (KEK). Pada graviditas I yaitu untuk pertama kali ibu hamil sehingga belum memiliki cukup pengalaman hamil dan bersalin yang akan mempengaruhi pengetahuan terutama mengenai kebutuhan nutrisi selama kehamilan. Sedangkan ibu hamil anak ke empat atau lebih (graviditas $\geq 4$ )akan berisiko mengalami KEK disebabkan oleh fungsi organ tubuh yang mulai melemah karena sering mengalami persalinan sehingga untuk menghadapi kehamilan yang sedang berlangsung, ibu memerlukan asupan energi yang cukup. Ibu dengan primigravida baru merasakan sesuatu yang asing hadir pada tubuhnya dimulai dengan mengetahui dirinya positif hamil, kemudian muncul perasaan cemas dan timbul pertanyaan apakah hamilnya akan berlangsung normal atau tidak hingga saat melahirkan. Keadaan tersebut menjadikan ibu hamil kurang mampu beradaptasi dengan perubahan yang terjadi sehingga keluhan mual, muntah dan kurang nafsu makan menjadi lebih berat pada trimester I. Hal ini akan mempengaruhi kebutuhan intake makanan dalam tubuh yang diperlukan untuk keberlangsungan proses kehamilan. Kurang asupan gizi pada trimester pertama ini yang menyebakan ibu mudah mengalami gizi kurang selama hamil.(Rahayu, 2015). Walaupun ibu hamil primipara maupun grandemultipara lebih berisiko mengalami gizi buruk namun mereka mampu untuk memenuhi asupan makanan yang dibutuhkan tubuh. Hal tersebut dapat terkait dengan lingkungan yang mendukung ibu dalam pemenuhan gizi selama kehamilan.

Berdasarkan ilmu perilaku Lawrence Green bahwa salah satu yang membentuk perilaku terkait dengan pengetahuan, sikap dan kebiasaan. Hal ini berlaku juga berlaku bahwa pengetahuan dan sikap terhadap makanan serta mempraktikkan pengetahuan tentang gizi harian berpengaruh terhadap kebiasaan diet dan pemilihan makanan. Pengembangan pola-pola konsumsi makanan dalam keluarga mempunyai 
asosiasi yang positif dengan pendidikan formal dari ibu rumah tangga. Pengetahuan dan praktik nutrisi bergantung pada tingkat pendidikan ibu, sehingga semakin tinggi pendidikan maka akan bertambah baik pengetahuan dan praktik nutrisinya. Hal tersebut terlihat dari upaya untuk memilih makanan yang bernilai nutrisi baik. Ibuibu rumah tangga yang mempunyai pengetahuan nutrisi dari pendidikan formal akan memilih makanan yang lebih bergizi. (Andriani, 2015). Mayorita ibu yang berpendidikan rendah maupun tinggi mengalami kenaikan berat badan selain itu karakteristik responden mayoritas ibu hamil KEK dengan pendidikan tinggi yaitu SMA sampai dengan sarjana. Hal ini dikarenakan walaupun ibu mempunyai pengetahuan nutrisi namun tidak dipungkiri bahwa kebiasaan makanan cepat saji dan minuman instan menjadi keharusan karena sifatnya yang praktis.

Ibu hamil dengan KEK pada awal semester memiliki keluhan yang lebih terutama pada keluhan mual muntah sehingga nafsu makan berkurang dan rata-rata terjadi penurunan berat badan. Hal tersebut yang menyebabkan ibu yang tadinya bekerja memutuskan mengundurkan diri dari pekerjaannya. Inilah yang menjadi alasan mengapa ibu-ibu dengan KEK ini hanya menjadi ibu rumah tangga saja atau tidak bekerja. Mayoritas ibu hamil KEK yang tidak bekerja maupun yang bekerja mengalami kenaikan berat badan sehingga tidak ada hubungan antara pekerjaan dengan kenaikan berat badan ibu hamil KEK. Hal tersebut tidak sejalan dengan penelitian sebelumnya bahwa terdapat hubungan antara pekerjaan dengan status gizi ibu hamil. (Bunga Widita Kartikasari, Mifbakhuddin, 2011). Hal tersebut terkait dengan pemenuhan makanan yang masih ditanggung oleh orang tua.

Hasil penelitian yang dilakukan sebelumnya terdapat hubungan peran suami dan ibu mertua/kandung dengan KEK. Peran suami dan mertua terkait dengan ketersediaan makanan yang bergizi, mitos seputar makanan, kebiasaan makan keluarga dan edukasi suami dan ibu mertua/kandung untuk menjaga kehamilannya. (Angraini, Ilmu, Komunitas, Kedokteran, \& Lampung, 2018). Keluarga adalah lingkungan terdekat ibu hamil. Mereka dapat memberikan motivasi ibu agar menjaga kehamilannya melalui nasihat, bertukar pengalaman dan menyediakan kebutuhanibuterkaitdenganpenyediaanmakanan yang bergizi minimal 3 kali dalam sehari. Menu yang diberikan keluarga memang seadanya tergantung dari bahan yang tersedia di rumah. Minimalnya dalam sehari mereka mengkonsumsi protein hewani maupun nabati seperti telur dan tempe. Selain itu mereka meyediakan sayuran bening dan buah-buahan sebagian pelengkap karena pencegahan terjadinya kurang Energi Kronis tidak hanya makanan yang cukup secara kuantitas namun dari segi kualitas.

Orang tua juga mendukung pilihan ibu dalam mengkonsumsi makanan, mengikuti selera makan ibu walaupun termasuk makanan yang dipantang. Aktivtas rutin yang dianjurkan oleh suami maupun orangtua adalah berjalan pagi, mengepel dan menyapu. Mereka juga menganjurkan ibu untuk cukup istirahat dengan tidur siang atau duduk-duduk sambil mengobrol dengan tetangga atau dinamakan "midang".

Kebiasaan pola makan sebelum hamil menjadi salah satu penyebab ibu mengalami KEK sehingga dengan perubahan yang terjadi diawal kehamilan ibu akan semakin kesulitan dalam pemenuhan kebutuhan makanan untuk janin dan tubuhnya. Hal ini menyebabkan terjadinya penurunan berat badan pada trimester I. Hal ini menjadi salah satu tugas bidan dalam mengedukasi ibu agar mengikuti anjuran makan sedikit-sedikit namun sering, menyelipkan cemilan seperti biskuit. Selain kuantitas dan kulitas makan ibu juga membutuhkan suplemen zat gizi yang harus dikonsumsi yaitu tablet tambah darah, kalsium, seng, vitamin A, vitamin 
D dan Iodium.

"dikasih vitamin aja buat suplemen makanan. Diminum habis, B komplek, b12, obat tambah darah setiap mau tidur sama kalsium, air putih $1 / 2$ gelas buat minum obat. bidan, sarannya sama makan yang banyak, makan bergizi, istirahat yang cukup"

Karena selain keluarga, ibu hamil sangat mendengar nasihat yang diberikan bidan. Hal ini sejalan dengan penelitian Manik bahwa yang memilki nilai tertinggi dalam menaikkan berat badan ibu hamil dengan KEK adalah peran bidan. Peran bidan sebagai fasilitator dapat sebagai penghubung dengan pihak terkait dalam hal ini puskesmas mengenai penyediaan pemberian makanan tambahan kepada ibu hamil setiap bulan. Sedangkan peran bidan sebagai konselor dilakukan dengan meningkatkan pengetahuan ibu tentang penambahan berat badan yang sesuai selama kehamilan, bahaya kehamilan dengan kekurangan energi kronik, asupan nutrisi yang baik selama kehamilan, melalui penyuluhan pada saat posyandu atau melalui konseling pada saat ibu memeriksaakan kehamilan secara rutin.(Manik \& Rindu, 2017). Oleh karenanya dibutuhkan keluarga yang mendorong dan menemani ibu melakukan pemeriksaan rutin dan minimalnya 8 kali sebelum umur kehamilan 24 minggu agar ibu bidan dapat memberikan informasi terkait asupan gizi yang baik agar terjadi peningkatan berat badan dan lingkar legan atas meningkat sehingga luaran dari kehamilan yaitu berat badan lahir bayi normal.

"kontrol seminggu sekali. Hasil pemeriksaan kadang bidannya juga keluhannya banyak, kurang istirahat. Anjuran istirahat aja diikutin. Mengikuti saran bidan praktik, kadang bengkeng ngga diikutin. Kadang masalah makanan ngga diikutin tapi dipikirin lagi, iya ya jadi mau diturutin"

\section{SIMPULAN DAN SARAN}

Berdasarkan hasil penelitian terdapat perbedaan kenaikan berat badan yang bermakna pada ibu hamil usia kehamilan 8 minggu dan kehamilan 24 minggu dengan KEK. Tidak ada hubungan antara Umur, paritas ,pendidikan dan pekerjaan dengan kenaikan berat badan ibu hamil KEK. Keluarga berkontribusi terhadap peningkatan kesehatan ibu hamil dengan penyediaan makanan bergizi, dan memotivasi menjaga kesehatan. Untuk Puskesmas agar melibatkan keluarga dalam pemberian informasi mengenai KEK. Untuk petugas kesehatan agar memberikan konseling mengenai KEK. Dianjurkan keluarga dapat mendorong atau mendampingi ibu periksa minimal 8 kali sebelum usia kehamilan 24 minggu.

\section{DAFTAR PUSTAKA}

Andriani, Z. (2015). Gambaran Status Gizi Ibu Hamil Berdasarkan Ukuran Lingkar Lengan Atas (LILA) di Kelurahan Sukamaju Kota Depok. Fakultas Kedokteran Dan Ilmu Kesehatan UIN Syarif Hidayatullah Jakarta, (Status Gizi Ibu Hamil berdasarkan Ukuran Lingkar Lengan Atas ( LILA )), 1-98.

Angraini, D. I., Ilmu, B., Komunitas, K., Kedokteran, F., \& Lampung, U. (2018). Hubungan Faktor Keluarga dengan Kejadian Kurang Energi Kronis pada Wanita Usia Subur di Kecamatan Terbanggi Besar The Association of Family Factors With Chronic Energy Deficiencies in Women of Childbearing Age in Terbanggi Besar Subdistrict, 2, 146-150.

Badan Pusat Statistik Kota Cirebon. (2016). Profil Kota Cirebon.

Bunga Widita Kartikasari, Mifbakhuddin, D. N. M. (2011). Hubungan Pendidikan, paritas, dan Pekerjaan Ibu Dengan Status Gizi 
Ibu Hamil Trimester III di Puskesmas Bangetayu Kecamatan Genuk Kota Semarang Tahun 2011. Jurnal Unimus, (3), 2 .

Chandradewi, A. A. S. P. (2015). Pengaruh Pemberian Makanan Tambahan Terhadap Peningkatan Berat Badan Ibu Hamil Kek (Kurang Energi Kronis) di Wilayah Kerja Puskesmas Labuan Lombok. Jurnal Kesehatan Prima, 9(1), 1391-1402. https://doi.org/10.32807/JKP.V9I1.61

Fikawati S, Safiq A, dan Karima K. (2015). Gizi Ibu dan Bayi. PT. Rajagrafindo Persada, Jakarta.

Huliana. (2010). Gizi Ibu Hamil. Penerbit Kanisius, Jakarta. (Vol. Penerbit K).

Kementerian Kesehatan Republik Indonesia. (2015). Pedoman Penanggulangan Kurang Energi kronik (KEK) Pada Ibu Hamil, 1-52.

Kementerian Kesehatan Republik Indonesia. (2017). Gizi dalam daur kehidupan. Jakarta.

Lubis, desi H. (2013). Hubungan Status Gizi ( Pertambahan Berat Badan Ibu selama Kehamilan dan Lingkar Lengan Atas
) dengan Berat Badan Bayi Lahir di Kecamatan Indralaya Utara, 4, 33-38.

Mahirawati, V. K. (2014). Ibu Hamil Kekurangan Energi Kronik (KEK): Jakarta., 193-202.

Manik, M., \& Rindu, R. (2017). Faktor yang Berpengaruh terhadap Kenaikan Berat Badan Ibu Hamil dengan KEK pada Trimester III. Jurnal Ilmiah Kesehatan, 16(2), 23-31. https://doi.org/10.33221/ jikes.v16i2.10

Rahayu, I. P. (2015). Hubungan Umur Dan Graviditas Dengan Kejadian Kekurangan Energi Kronik (Kek) Pada Ibu Hamil Di Puskesmas Lepo-Lepo Kota Kendari Provinsi Sulawesi Tenggara Tahun. Skripsi, 151, 10-17.

Sri, N. K., \& Putri, E. (2018). Hubungan Usia Ibu dengan Peningkatan Berat Badan selama Hamil di Kabupaten Karanganyar, II(4), 255-258.

Varney, H. (2006). Buku Ajar Asuhan Kebidanan (4th ed.). Jakarta: EGC.

WHO. (2015). Regional Nutrition Strategy: Addressing malnutrition and micronutrient deficiencies. 
